\title{
Systemic lupus erythematosus presenting to haematology with pancytopenia and features of macrophage activation syndrome
}

\author{
Jayna Mistry, ${ }^{1}$ Graham Knee, ${ }^{2}$ Vishal Jayakar ${ }^{1}$
}

${ }^{1}$ Department of Haematology, Kingston Hospital NHS Foundation Trust, Kingston upon Thames, UK

${ }^{2}$ Department of Histopathology, Kingston Hospital NHS

Foundation Trust, Kingston upon Thames, UK

Correspondence to Dr Jayna Mistry,

jaynamistry@doctors.org.uk

Accepted 1 February 2018
Check for updates

To cite: Mistry J, Knee G Jayakar V. BMJ Case Rep Published Online First: [please include Day Month Year]. doi:10.1136/bcr-2017 222096

\section{DESCRIPTION}

This bone marrow biopsy (figure 1) shows haemophagocytosis consistent with macrophage activation syndrome (MAS) secondary to previously undiagnosed systemic lupus erythematosus (SLE).

A 44-year-old woman had been unwell for 4 weeks with fever, weight loss and an aphthous ulcer. There were no other clinical features of SLE.

There was pancytopenia (platelet count $65 \times 10^{9} / \mathrm{L}$; neutrophil count $0.5 \times 10^{9} / \mathrm{L}$; haemoglobin $107 \mathrm{~g} / \mathrm{L}$ ). The reticulocyte count was $20 \times 10^{9} /$ L. Parvovirus and Epstein-Barr virus IgM were not detected.

A very high ferritin level of $3717 \mu \mathrm{g} / \mathrm{L}$ in the context of cytopenias was suggestive of MAS, a life-threatening hyperinflammatory state. ${ }^{1}$ Clinical features of MAS include fever, lymphadenopathy and hepatosplenomegaly. Laboratory markers include pancytopenia, altered liver function and coagulopathy, with raised lactate dehydrogenase (LDH) and triglycerides. ${ }^{2}$

This patient had raised aspartate transaminase and alanine transaminase levels $(154$ and $145 \mathrm{U} / \mathrm{L}$, respectively). The LDH level was high $(458 \mathrm{U} / \mathrm{L})$. The triglyceride level was $2.07 \mathrm{mmol} / \mathrm{L}$. There was no coagulopathy. The C-reactive protein level was $3.2 \mathrm{mg} / \mathrm{L}$. There was a raised urine protein to creatinine ratio $(>200)$.

Antinuclear antibody titres were raised (1/160640). The anti-double-stranded DNA level was high at $>379 \mathrm{IU} / \mathrm{mL}$, which alongside ulceration, cytopenias and proteinuria yielded a diagnosis

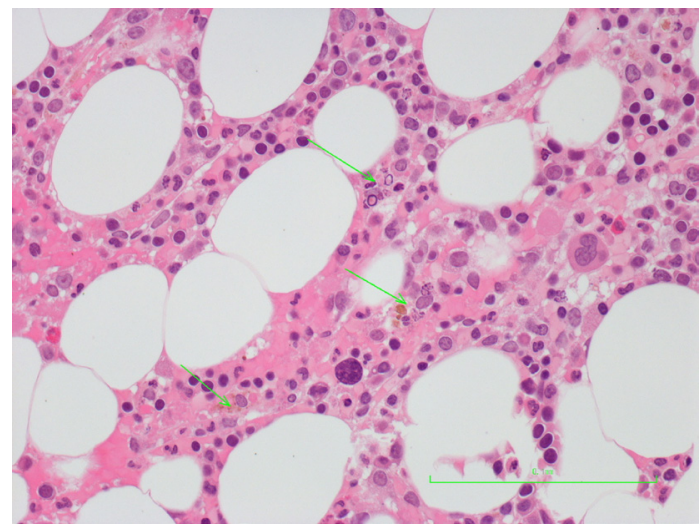

Figure 1 Bone marrow biopsy with abundant cellbound haemosiderin and focal haemophagocytosis with cellular debris identified in macrophage cytoplasm (arrows). This is consistent with, but not specific for, macrophage activation syndrome.

\section{Patient's perspective}

"My SLE does affect my everyday life but I always think positively and feel very lucky - I feel better since the diagnosis."

"My hair is falling out which is depressing and I have to clean my room three times a week. Sometimes I have to do tasks slowly. Hot weather and stress makes it worse- my left ankle becomes swollen and I have an awareness of the joints in my toes. Initially I was not able to open bottles or peel onions but my joints are better now."

"I also bruise easily with steroids."

\section{Learning points}

- Uncommonly, systemic lupus erythematosus and other autoimmune or rheumatological disorders can present with macrophage activation syndrome (MAS), a life-threatening hyperinflammatory state where there is a constellation of fever with pancytopenia, with high ferritin, aspartate transaminase and triglyceride levels. The fibrinogen level is low.

- A very high serum ferritin level should trigger MAS as a differential, especially if the C-reactive protein level is normal or modestly elevated.

- Cytopenias with MAS secondary to autoimmune disease can respond to steroids alone, as in this case, as opposed to requiring chemotherapy. ${ }^{3}$

of SLE. Complement levels were low (C3 $0.3 \mathrm{~g} / \mathrm{L}$ and $\mathrm{C} 40.1 \mathrm{~g} / \mathrm{L}$ ), indicating active disease. The cytopenias and clinical features responded well to prednisolone.

While the cytopenias may have been autoimmune in aetiology, the high ferritin level and bone marrow biopsy findings make MAS a likely contributing factor.

Contributors JM wrote the manuscript. GK provided the histopathology image and interpretation. VJ edited the manuscript.

Competing interests None declared.

Patient consent Obtained.

Provenance and peer review Not commissioned; externally peer reviewed.

(c) BMJ Publishing Group Ltd (unless otherwise stated in the text of the article) 2018. All rights reserved. No commercial use is permitted unless otherwise expressly granted. 


\section{REFERENCES}

1. Brisse $E$, Matthys $P$, Wouters $C H$. Understanding the spectrum of haemophagocytic lymphohistiocytosis: update on diagnostic challenges and therapeutic options. $\mathrm{Br} J$ Haematol 2016;174:175-87.

2 Ravelli A, Minoia F, Davi S, et al. 2016 Classification criteria for macrophage activation syndrome complicating systemic juvenile idiopathic arthritis: A European
League against Rheumatism/American College of Rheumatology/Paediatric Rheumatology International Trials Organisation Collaborative Initiative. Ann Rheum Dis 2016;75:481-9.

3 Gavand PE, Serio I, Arnaud L, et al. Clinical spectrum and therapeutic management of systemic lupus erythematosus-associated macrophage activation syndrome: A study of 103 episodes in 89 adult patients. Autoimmun Rev 2017;16:743-9.

Copyright 2018 BMJ Publishing Group. All rights reserved. For permission to reuse any of this content visit

http://group.bmj.com/group/rights-licensing/permissions.

BMJ Case Report Fellows may re-use this article for personal use and teaching without any further permission.

Become a Fellow of BMJ Case Reports today and you can:

- Submit as many cases as you like

- Enjoy fast sympathetic peer review and rapid publication of accepted articles

- Access all the published articles

Re-use any of the published material for personal use and teaching without further permission

For information on Institutional Fellowships contact consortiasales@bmjgroup.com

Visit casereports.bmj.com for more articles like this and to become a Fellow 